\title{
Exploring Students' Evaluation Criteria in Using ELL Websites
}

\author{
Sarah Abdulgani Alzaidi \\ English Language Institute, King Abdulaziz University, Jeddah, KSA \\ E-mail: sralzaidi@stu.kau.edu.sa \\ Dr. Maha Saeed Halabi (Corresponding author) \\ English Language Institute, King Abdulaziz University, Jeddah, KSA \\ E-mail:mshalabi@kau.edu.sa
}

Received: May 1, 2020 Accepted: June 12, 2020 Published: June 17, 2020

doi:10.5296/elr.v6i2.16942ＵRL: https://doi.org/10.5296/elr.v6i2.16942

\begin{abstract}
English language learning (ELL) websites are now regarded as one of the most important tools in learning language skills (listening, speaking, reading, and writing). Therefore, this study aimed to investigate how a number of 36 female high school students aged between 16 and 18 years old in Saudi Arabia would evaluate ELL websites. The study adapted evaluation criteria from Yang and Chan (2008), who developed valid criteria for evaluating the ELL websites. The present study explored students' evaluation criteria in ELL websites by distributing an electronic questionnaire consisted of 15 items. The evaluation criteria were information on the author, listening, speaking, reading, and writing on ELL websites. The results are analyzed by using SPSS Version 21 . The descriptive results indicate that students have high evaluation criteria in terms of reading and listening skills. On the other hand, Information on the author, writing, and speaking skills had the lowest evaluation criteria, receptively. Finally, this study was concluded with a discussion addressed the importance of enhancing students' evaluation criteria in order to promote their digital literacy.
\end{abstract}

Keywords: Criteria, Evaluation, English language websites, ELL websites, Digital literacy, Language skills 


\section{Introduction}

'Google it' is widespread phrase in the 21 st century. 'Google it' usually refers to conducting a research process about a particular information through using Google search engine. Students depends frequently on Google search engine to find websites as resource of learning. A wide range of English learning resources and websites appear for students after one click only. For example, if we write 'English Learning' in Google search engine, almost 408,000,000 million results are made available immediately, according to Google Chrome. As a result, investigating how students, examine, analyze, and evaluate information must be put into consideration. Moreover, online searching is a main and effective factor in the educational process nowadays. For this purpose, the present study examines a set of criteria that Saudi students adapt on English language learning websites. The criteria involve the four language skills listening, reading, writing, and speaking. Also, the criteria encompass information on the author or developer of the content in the website. This study aims to measure students' evaluation criteria on using ELL websites, and shed light on the importance of developing students' awareness of the quality and validity of the information on ELL websites.

\subsection{Statement of the Problem}

To the best of our knowledge, no existing study has empirically and quantitatively investigated Saudi students' evaluation criteria in using ELL websites. Multiple evaluation criteria are constantly developed and designed; however, none of the previous research studies have analyzed how students use or adapt these evaluation criteria. Also, there have been a small number of studies that have explored students' attitudes or perception while using websites or Web 2.0 to learn English language. Due to the dominance of social networks in the last decade, most existing studies have focused intensively on social networks (Facebook, Twitter, and YouTube) rather than websites. Consequently, more studies are needed about websites and pedagogical practices. Therefore, this study focused on students' evaluation criteria while using language learning websites to fill this research gap.

\subsection{The Aim of The Study}

The present study aims to establish a comprehensive understanding of the following points:

- Explore the criteria that Saudi students follow while using ELL websites.

- Determine students' digital literacy levels while using ELL websites.

\subsection{Research Questions}

The present study seeks to address the following research questions:

- What are the evaluation criteria that Saudi students follow when using English language learning websites?

- To what extent do Saudi students follow these criteria?

\section{Literature Review}

\subsection{The Importance of ELL Websites and Web 2.0}


Websites are extremely useful technical instruments that enable students to have an access to a variety of learning resources, which can facilitate their language learning. In terms of content, websites contain intensive authentic materials that connects students' learning experience directly with the real usage of language. Involving students with organized and systematic digital authentic materials have increased the level of their participation and commitment in the classroom environment (Johnson, 2016). In addition to digital authentic materials, constant availability is another significant aspect in websites. Students can use websites in different contexts inside and outside of the classroom. This means students have an opportunity to be autonomous leaners in a context that exists outside classroom. Therefore, autonomous and independent learning is connected directly to the use of technology. According to Wang and Peverly (1986), autonomy is defined when students have the responsibility to use effective learning strategies and make decisions correctly and independently. Finally, the nature of websites is evolving constantly. The new generation of Web 2.0 or Read-Write Web enables Internet users to have an active role on websites. For example, users have the opportunity to be a reader and writer simultaneously (Rosen \& Nelson, 2008). As a result, Web 2.0 users now have a free access to websites content. Also, they are able to add, modify, and create content in the Internet and websites. Because of the unlimited and open access and editing in Web 2.0 generation, the validity of the content of ELL websites might be affected negatively.

\subsection{Defining Evaluation Criteria}

According to Oxford online dictionary (2020), criterion can be defined as "a standard or principle by which something is judged, or with the help of which a decision is made." More precisely, criteria are assumed to be a guidance that directs individuals' final judgment about their choices, whether consciously or unconsciously. 'Checklist' is another term can be considered as a synonym for criterion. Some institutions have established a checklist as a guide to make websites users evaluate more effectively the content in the Internet. For example, the University of Southern Maine published a checklist to enhance the concept of evaluating learning resources in the Internet. In the academic and research studies, researchers designed various evaluation criteria to validate the assisting process of websites (Morris, 2018; Kim, Eng, Deering \& Maxfield, 1999). Moreover, researchers and educators assumed that if leaners have a clear set of rules and criteria, they will be able to make a correct decision in their learning process that takes place in websites. However, previous research studies examined the evaluation criteria of websites in general. On the other hand, Yang and Chan (2008) emphasized that learning English language has unique features and characteristic other than learning any type of knowledge. Subsequently, they developed particular and specific evaluation criteria for English language learning websites by establishing a theoretical and pedagogical basis for their criteria, and the researchers reviewed previous literature that established evaluation criteria. Finally, the elements and items of any evaluation criteria or checklist might vary and differ according to the perspective of the research study. However, the purpose is unified, which is exploring and examining a valid and reliable content of the websites that exist on the Internet. 


\subsection{Students'Learning Experience While Using ELL Websites}

From a student perspective, a large and growing body of literature have demonstrated that ELL websites offer for students more successful and dynamic language learning experience. Also, many of ELL websites have efficiently covered all language skills (listening, reading, writing, and speaking). This section focuses more precisely on some of the common learning experiences in ELL websites. We will display research studies that explored students' experiences, in learning vocabulary in reading, pronunciation in speaking, writing through discussion forums, and self-evaluation in listening.

In learning reading and vocabulary, online activities and web-based language learning have remarkably facilitated the acquisition of vocabulary over a short period of time (Hajebi, Taheri, Fahandezh, \& Salari, 2018). Similarly, Wang (2014) concluded that web-based vocabulary exercises in reading comprehension exams increased students' scores.

Enhancing collaborative practices among students in writing skill have highly been connected to the usage of websites. For example, Hunter (2011) revealed that electronic discussion forums provide successful communication, which develops the accuracy of the written text; moreover, students showed a remarkable collaboration with each other. Hunter (2011) also found that online writing groups on Wiki platforms and discussion forums allowed learners to share their cultures, ideas, and thoughts. In addition to communication and collaboration, students' grammatical errors and punctuation are less repeatedly recorded in online collaborative writing (Kessler, Bikowski, \& Boggs, 2012). As a result, we can demonstrate that one of the dominant and recent tendencies in the educational field, namely the negotiation of meaning and group work among students, can be applicable more easily through using websites.

Many studies have been published on the enhancement of different speaking skills by practicing through websites, one of which is pronunciation. For instance, Köroğlu and Çakır (2017) found that students' pronunciation was improved significantly after implementing flipped classroom, because they had enough time to practice pronouncing before class time. In fact, the implementation of speaking exercises in many cases cannot be done sufficiently in the classroom for multiple reasons. For example, Soureshjani and Riahipour (2012) noted that one of the most discouraging factors that decreases the usage speaking activities in classrooms was the limited amount of time. However, this issue may be addressed with using websites.

Multiple listening strategies can be used in web-based language learning. For example, based on O'Malley and Chamot's (1990) taxonomy of listening strategies, Chen, Zhang, and Liu (2014) found that metacognitive strategies, such as when students examine and evaluate themselves in listening, are the most used strategy. Also, in the present study we will focus on metacognitive strategies, particularly the strategies that related to self-evaluation as a criterion of evaluation. In conclusion, Alnujaidi (2017) found that students have positive experiences in learning English through social networks; however, learning experience did not correlate with their perceptions. This issue should be addressed because experience should not be separated from perception. Rao and Narayan (1998) found that, if people have 
a positive perception, they will be able to organize and select content or information more accurately (as cited in Alnujaidi, 2017).

\section{Methodology}

\subsection{Participants}

The participants were 36 female high school students from Saudi Arabia aged between 16-18 years old. The students are studying in two different public schools. The convenience sampling strategy was used to select the participants. According to Dornyei (2007), convenience sampling is recommended to use when participants are available and accessible to the researcher for a limited time.

\subsection{Instrument}

The methodology of this research was quantitative and adapted a questionnaire as the main instrument of data collection. The multi-item scales of the questionnaire were adapted from Yang and Chan (2008), who developed a variety of evaluation criteria of ELL websites in order to guide learners to choose a reputable website. Moreover, the researchers test the validity of these criteria by investigating experts' points of view and previous findings. The findings of Yang and Chan (2008) were forty-six evaluation criteria divided into six categories, namely listening, writing, speaking, reading, general information, and integrated English learning.

The present study adapted the aforementioned categories except integrated English learning. Also, each category encompasses three items. As a result, the total number of items in the questionnaire was 15 items that were adapted from the evaluation criteria that designed by Yang and Chan (2008). Furthermore, the questionnaire contained a four-point scale (1= I strongly care, $2=$ I partly care, $3=$ I do not care, $4=$ I do not care at all). The questionnaire included demographic information, such as the level of education and the level of English language.

\subsection{Data collection and Analysis}

The questionnaire was designed by using Google Forms. The items on the questionnaire were translated from English to Arabic by the researcher, who contacted participants through WhatsApp, Twitter, and Telegram groups to fill the form electronically. Finally, research ethical principles were followed. The privacy and anonymity of 36 participants were considered and assured. Furthermore, all of the responses were saved only for the research purposes, and the participants were informed of the purpose of the study. Additionally, the participants were informed that there is not a correct or incorrect answer to ensure the sincerity and validity of their responses. Data were organized by using Microsoft Excel 2019. After the process of organizing, the data were entered into SPSS Version 21 to start the descriptive analysis.

\section{Results and Discussion}

The analyzing process of the questionnaire in SPSS Version 21 has started with a reliability 
analysis. The results of the test were acceptable at 0.755. According to Dorney (2007), Cronbach's Alpha must be above 0.60 to ensure the reliability of the questionnaire.

Table 1. Results of the Cronbach's Alpha test

\begin{tabular}{|l|l|}
\hline Reliability statistics & N of Items \\
\hline Cronbach's Alpha & 15 \\
\hline .755 & \\
\hline
\end{tabular}

The questionnaire was categorized in descending order (from $4=\mathrm{I}$ do not care at all to $1=\mathrm{I}$ strongly care). If the results of mean scores shown in the tables are high, the students have low criteria. On the other hand, if the results shown in the tables are low, students have high criteria.

Table 2. Results of Author items

\begin{tabular}{|l|l|l|l|l|l|}
\hline Item & $\mathbf{N}$ & Minimum & Maximum & Mean & $\begin{array}{l}\text { Std. } \\
\text { Deviation }\end{array}$ \\
\hline $\begin{array}{l}\text { Users can link to information about the } \\
\text { sponsor and author }\end{array}$ & 36 & 1.0 & 4.0 & 2.444 & .9984 \\
\hline $\begin{array}{l}\text { The author is an expert or is qualified } \\
\text { to deliver reputable resources }\end{array}$ & 36 & 1.0 & 4.0 & 1.639 & .7617 \\
\hline $\begin{array}{l}\text { Users can contact authors for } \\
\text { clarification }\end{array}$ & 36 & 1.0 & 4.0 & 1.833 & .9710 \\
\hline
\end{tabular}

The primary objective of this study was to explore the evaluation criteria of students when using ELL websites. The first research question referred to the evaluation criteria that Saudi students used when using ELL websites. The findings were varied and demonstrated that the evaluation criteria on author information were the lowest results as shown in Table 2 . Although communication with the author may provide students with considerable knowledge, the results concluded that there was not a clear concern among students to communicate with the author of the content. Moreover, most of the students did not appear to possess an interest in the author's scientific qualifications. However, students should be cautious about the professional information of the content creator. According to Hockly (2015), online learning environment might involve teachers or instructors who are not qualified enough to teach the language or establish a reliable pedagogical content.

Table 3. Results of writing items

\begin{tabular}{|l|l|l|l|l|l|}
\hline Item & N & Minimum & Maximum & Mean & $\begin{array}{l}\text { Std. } \\
\text { Deviation }\end{array}$ \\
\hline Users can discuss the writing & 36 & 1.0 & 4.0 & 1.778 & .8980 \\
\hline
\end{tabular}




\begin{tabular}{|l|l|l|l|l|l|}
\hline $\begin{array}{l}\text { content with instructors online } \\
\text { (e.g. via email or discussion } \\
\text { boards) }\end{array}$ & & & & & \\
\hline $\begin{array}{l}\text { Discussion boards are provided } \\
\text { for students to exchange } \\
\text { opinions }\end{array}$ & 36 & 1.0 & 4.0 & 1.833 & .9103 \\
\hline $\begin{array}{l}\text { Users can observe others } \\
\text { people's written works online }\end{array}$ & 36 & 1.0 & 4.0 & 1.722 & 1.0032 \\
\hline
\end{tabular}

In terms of the evaluation criteria in writing skill, this research focused on writing and discussion. Students were asked to clarify preferences regarding learning writing through discussions on ELL websites with both experts or learners. The findings in Table 3 exposed that there was a clear hesitation about developing writing skill through discussion in ELL websites. However, exchanging opinions and feedback can affect writing skills positively. Furthermore, collaborative discussion in writing is a learning style that can affect key skills in writing such as accuracy (Hunter, 2011; Kessler, Bikowski, \& Boggs, 2012).

Table 4. Results of speaking items

\begin{tabular}{|l|l|l|l|l|l|}
\hline Item & N & Minimum & Maximum & Mean & $\begin{array}{l}\text { Std. } \\
\text { Deviation }\end{array}$ \\
\hline $\begin{array}{l}\text { The website includes } \\
\text { colloquial usages (e.g. local } \\
\text { communicative speech) }\end{array}$ & 36 & 1.0 & 4.0 & 1.444 & .8087 \\
\hline $\begin{array}{l}\text { The website presents } \\
\text { pronunciation skills (e.g. the } \\
\text { mouth of /e/ in } \\
\text { pronunciation) }\end{array}$ & 36 & 1.0 & 4.0 & 1.806 & 1.0642 \\
\hline $\begin{array}{l}\text { The website presents skills } \\
\text { of using intonation correctly }\end{array}$ & 36 & 1.0 & 4.0 & 1.944 & 1.1697 \\
\hline
\end{tabular}

The evaluation criteria of speaking skill were the third lowest result. For example, the results revealed that the majority of the students were not concerned with skills of intonation and pronunciation. In reality, practicing pronunciation skill through ELL websites can significantly enhance speaking skills (Köroğlu \& Çakır, 2017). As a result, students should not neglect the criterion of pronunciation skill. On the other hand, students are more attracted to content, which includes information on colloquial usage in speaking. Consequently, this means that students are more motivated to interact with native speaker culture in speaking rather than learning intonation and pronunciation. 
Table 5. Results of listening items

\begin{tabular}{|l|l|l|l|l|l|}
\hline Item & N & Minimum & Maximum & Mean & $\begin{array}{l}\text { Std. } \\
\text { Deviation }\end{array}$ \\
\hline $\begin{array}{l}\text { The listening comprehension } \\
\text { takes place in authentic } \\
\text { situations (e.g. conversation in } \\
\text { the restaurant) }\end{array}$ & 36 & 1.0 & 4.0 & 1.722 & .9743 \\
\hline $\begin{array}{l}\text { The listening comprehension is } \\
\text { designed to guide users to } \\
\text { answer the questions (e.g. the } \\
\text { questions and listening content } \\
\text { are relevant) }\end{array}$ & 36 & 1.0 & 3.0 & 1.556 & .6947 \\
\hline $\begin{array}{l}\text { The listening comprehension } \\
\text { includes self-examining } \\
\text { questions }\end{array}$ & 36 & 1.0 & 4.0 & 1.472 & .8447 \\
\hline
\end{tabular}

Table 6. Results of reading items

\begin{tabular}{|l|l|l|l|l|l|}
\hline Item & $\mathbf{N}$ & Minimum & Maximum & Mean & $\begin{array}{l}\text { Std. } \\
\text { Deviation }\end{array}$ \\
\hline $\begin{array}{l}\text { New vocabulary is } \\
\text { accompanied with resources } \\
\text { of its synonyms }\end{array}$ & 36 & 1.0 & 4.0 & 1.500 & 1.0000 \\
\hline $\begin{array}{l}\text { New vocabulary is presented } \\
\text { using special forms (e.g. } \\
\text { using different colors or bold } \\
\text { to identify the new } \\
\text { vocabulary) }\end{array}$ & 36 & 1.0 & 4.0 & 1.389 & .7664 \\
\hline $\begin{array}{l}\text { There is a section to instruct } \\
\text { about the new vocabulary }\end{array}$ & 36 & 1.0 & 3.0 & 1.333 & .5855 \\
\hline
\end{tabular}

The evaluation criteria of listening and reading were the highest results as shown in Table 5 and 6. Combining metacognitive strategies, such as self-examining in listening, was preferred by most of the students. This self-assessment may evolve students' ability to determine their strengths and weaknesses. Similarly, in reading, presenting vocabularies in innovative ways such as colors and sizes was favorable for students. This system can be a helpful learning strategy for visual learners. According to Ellis (1995: 89), 'no noticing, no acquisition', which means presenting a new knowledge in a way that attract students' notice might foster their acquisition of the language. As a result, students will be able to acquire new vocabulary 
if it is presented more creatively on ELL websites.

Regarding the second research question, students registered only two high evaluation criteria in reading and listening. On the other hand, a low evaluation criterion was afforded to authors' information, speaking, and writing. Therefore, students, to some extent, do not evaluate ELL websites effectively. Moreover, students' digital literacy in terms of evaluating content and choosing reputable ELL websites that enhance their skills is minimal. This finding aligns with those of Al Seghayer (2020) who revealed that students are not fully qualified to handle online research performance because they lack digital literacy.

This problem can be addressed with teachers' support. Due to the diversity of English language learning websites, teachers should direct and guide students to help them make appropriate evaluations and choices for ELL websites. Thnah (2011) explored teachers' perceptions of the learning context that existed outside of the classroom. He found that most of the teachers believed that students must be fully responsible about any learning process that happens outside of the classroom. Although this statement may be true; however, some of the students need advice and guidance in the initial stages of their learning and searching process. According to Lai, Yeung, and $\mathrm{Hu}$ (2016), teachers' recommendations of technological sources enhance autonomous language learning. To summarize, teachers' choices and adaptation of technology is mostly adapted by their students (Fagerlund, 2012). As a result, teachers must be aware of this responsibility and try to increase their students' awareness about proper criteria when using ELL websites. Also, teachers should give their students lessons about online research and apply it during classroom time.

\section{Conclusion and Limitations}

In conclusion, this study examined students' evaluation criteria when using ELL websites. The findings confirmed that students needed to be more aware of the importance of authors' professional information, pronunciation, and intonation in speaking, and discussions forums in writing in ELL websites. As a result, increasing students' awareness and improving their criteria will make them choose more effective websites to learn English language skills.

ELL websites encompass different tools and content. Further study may investigate students' evaluation criteria from different perspectives. Due to this study's limitations, this study was not an experimental investigation. Future research may conduct experimental research to determine the effect of increasing students' awareness of ELL websites in language proficiency. Also, future research should examine evaluation criteria in different population; for example, the evaluation criteria of university students. To generalize the findings, future studies should expand the number of participants, and indicate a qualitative instrument.

\section{References}

Al Seghayer, K. (2020). Investigating the adequacy of EFL learners' L2 digital literacy Skills, consistency of self-assessed competence, and actual performance. International Journal of Computer-Assisted Language Learning and Teaching (IJCALLT), 10(2), 1-22. https://doi.org/10.4018/IJCALLT.2020040101 
Alnujaidi, S. (2017). Social network sites effectiveness from EFL students' viewpoints. English Language Teaching, 10(1), 39-49. https://doi.org/10.5539/elt.v10n1p39

Chen, L., Zhang, R., \& Liu, C. (2014). Listening strategy use and influential factors in Web-based computer assisted language learning. Journal of Computer Assisted Learning, 30(3), 207-219. https://doi.org/10.1111/jcal.12041

Criterion. (n.d.). In Oxford online dictionary. Retrieved from https://www.oxfordlearnersdictionaries.com/definition/english/criterion

Dornyei, Z. (2007). Research methods in applied linguistics. Oxford University Press.

Ellis, R. (1995). Interpretation tasks for grammar teaching. Tesol Quarterly, 29(1), 87-105. https://doi.org/10.2307/3587806

Fagerlund, T. (2012). Learning and using English and Swedish beyond the classroom: Activity systems of six upper secondary school students. (Unpublished master's thesis). Jyväskylä, Finland: University of Jyväskylä.

Hajebi, M., Taheri, S., Fahandezh, F., \& Salari, H. (2018). The role of web-based language teaching on vocabulary retention of adult pre-intermediate EFL learners. Journal of Language Teaching and Research, 9(2), 372-378. https://doi.org/10.17507/j1tr.0902.20

Hockly, N. (2015). Developments in online language learning. Elt Journal, 69(3), 308-313. https://doi.org/10.1093/elt/ccv020

Hunter, R. (2011). Erasing "property lines": A collaborative notion of authorship and textual ownership on a fan wiki. Computers and Composition, 28(1), 40-56. https://doi.org/10.1016/j.compcom.2010.12.004

Johnson, A. D. (2016). Designing 'authenticity' in digital learning environments. Journal of Interactive Technology and Pedagogy, 9.

Kessler, G., Bikowski, D., \& Boggs, J. (2012). Collaborative writing among second language learners in academic web-based projects. Language Learning \& Technology, 16(1), 91-109.

Kim, P., Eng, T. R., Deering, M. J., \& Maxfield, A. (1999). Review of published criteria for evaluating health-related Web sites. Western Journal of Medicine, 170(6), 329.

Köroğlu, Z. Ç., \& Çakır, A. (2017). Use of flipped instruction in language classrooms: An investigation about student students teachers' perceptions. European Journal of English Language Teaching.

Lai, C., Yeung, Y., \& Hu, J. (2016). University student and teacher perceptions of teacher roles in promoting autonomous language learning with technology outside the classroom. Computer Assisted Language Learning, 29(4), 703-723. https://doi.org/10.1080/09588 221.2015.1016441

Morris, k. (2018, November 20). How to evaluate websites: A guide for teachers and students (Free Poster). Retrieved from 


\section{Macrothink}

http://www.kathleenamorris.com/2018/11/20/evaluate-websites/

O’Malley, J. M., \& Chamot, A. U. (1990). Learning strategies in second language acquisition. Cambridge: Cambridge University Press. https://doi.org/10.1017/CBO 9781139524490

Rosen, D., \& Nelson, C. (2008). Web 2.0: A new generation of learners and education. Computers in the Schools, 25(3-4), 211-225. https://doi.org/10.1080/07380560802370997

Soureshjani, K. H., \& Riahipour, P. (2012). Demotivating factors on English speaking skill: A study of EFL language learners and teachers' attitudes. World Applied Sciences Journal, 17(3), 327-339.

Thanh, Van N. (2011). Language learners' and teachers' perceptions relating to learner autonomy Are they ready for autonomous language learning? VNU Journal of Science, Foreign Languages, 27, 41-52.

University of Southern Maine. Checklist for evaluating web resources. Retrieved from https://usm.maine.edu/library/checklist-evaluating-web-resources\#

Wang, M. C. and Peverley, S. T. (1986) The Self-instructive process in classroom learning

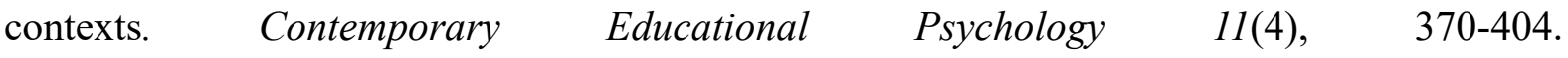
https://doi.org/10.1016/0361-476X(86)90031-7

Wang, Y. H. (2014). Use of interactive web-based exercises for English as a foreign language learning: Learners' perceptions. Teaching English with Technology, 14(3), 16-29.

Yang, Y. T. C., \& Chan, C. Y. (2008). Comprehensive evaluation criteria for English learning websites using expert validity surveys. Computers \& Education, 51(1), 403-422. https://doi.org/10.1016/j.compedu.2007.05.011

\section{Glossary}

ELL: English language learning. 


\section{Appendix}

Appendix 1. Survey Question in Arabic language

\section{قياس معايير الطالبات أثناء استخدام مواقع تعليم اللغة الإنجليزية}

تهدف هذه الدر اسة الى تقييم معايير الطالبات أثناء تصفح مو اقع تعليم اللغة الإنجليزية. الرجاء تعاء تعبئة الاستبانة التالية:

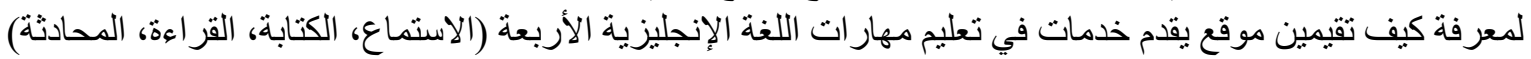

$$
\text { (لا توجد إجابة صحيحة أو خاطئة) }
$$

مستوى التعليم:

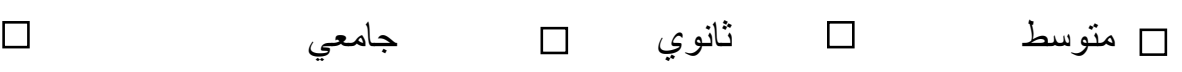
در اسات عليا

كيف تقيمين مستو الك فى اللغة الانجليزية؟

منقدم

مبتدى

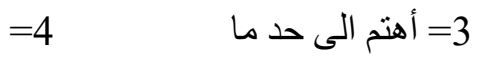

2

=1 أهنم جدا

طريقة الاختيار:

\begin{tabular}{|c|c|c|c|c|c|}
\hline 4 & 3 & 2 & 1 & 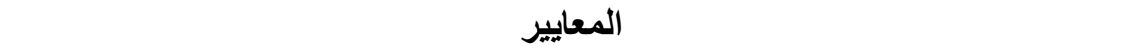 & \\
\hline & & & & 1- أهتم بأن يوفر الموقع معلومات عن مؤسس الموقع & To: \\
\hline & & & & 2- أهتم بأن يكون مؤسس الموقع ذو خبرة ومؤهل عالي & $\xi$ \\
\hline & & & & 3- أهتم بتوفر طرق للتو اصل مع مؤسس الموقع في حال احتجت لتوضيح شيء معين & \\
\hline & & & & 4- أهتم بأن يوفر الموقع محتوى استماع عن مواقف في الحياة اليومية (مثنا: محادثة & $\boldsymbol{r}$ \\
\hline & & & & 5- أهتم بأن يكون محتوى الاستماع و أسئلة الاستماع متر ابطة & \\
\hline & & & & 6- أهتم بأن يكون في محتوى الاستماع أسئلة اختبر بها مستوى فهمي & $\Phi$ \\
\hline & & & & 7ـ أهتم بأن يوفر الموقع أمثلة على طرق استخدام اللغة الإنجليزية العامية في مهارة & [** \\
\hline & & & & 8- أهتم بأن يوفر الموقع شرح لطرق النطق الصحيح للأحرف مثلا: طريقة نطق & $\frac{E}{E}$ \\
\hline & & & & 9- أهنم بأن يوفر الموقع شرح (مهارات رفع وخفض الصوت) في مهارة التحدث & \$ \\
\hline & & & & 10- أهتم بأن يكون في الموقع مفردات للكلمات الجديدة & 㠳 \\
\hline
\end{tabular}

لا أهتم إطلاقا 


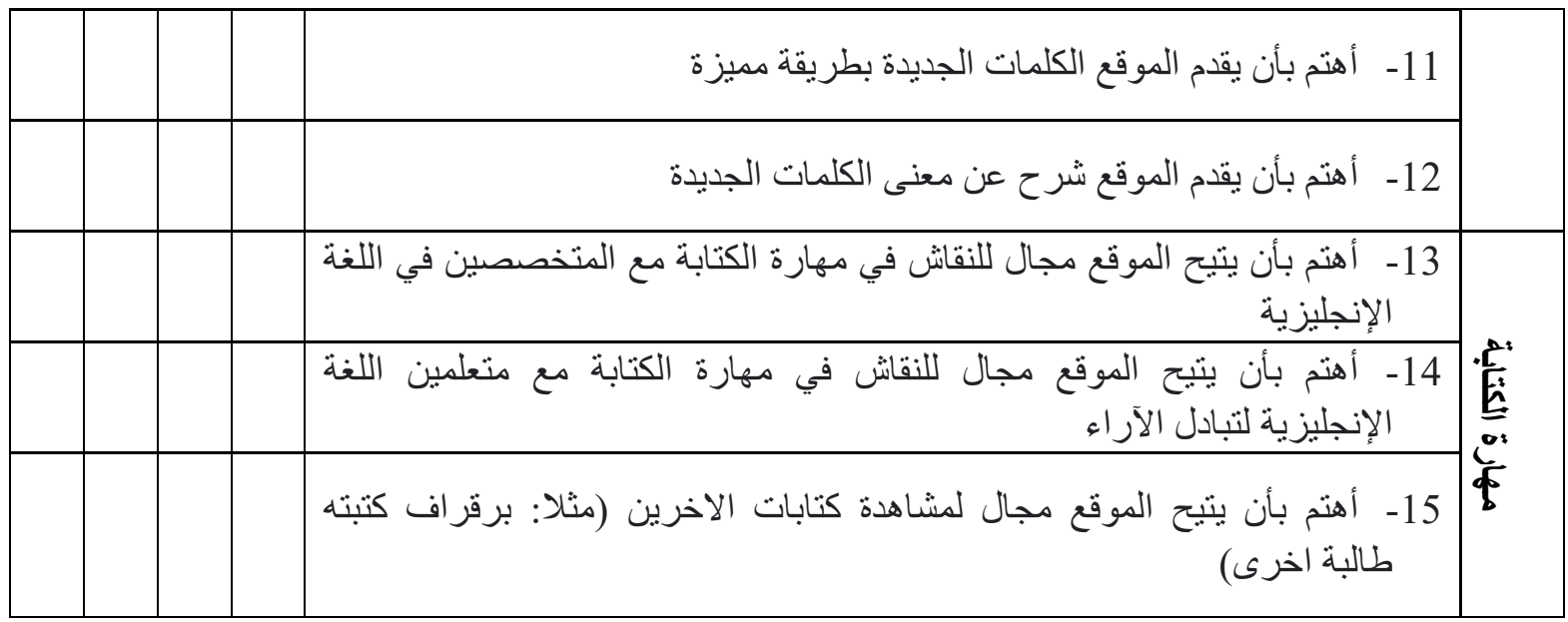

$$
\text { مترجم من اللفة الإنجليزية الى اللفة العربية }
$$

Yang and Chan (2008)

Appendix 2. Survey Question in English language

\section{Evaluating students' evaluation criteria}

This study aims to examine students' evaluation while using English language learning websites. There is not wrong and right. Thank you.

\section{Education level}

$\square$ Intermediate

High school

Bachelor

Graduate

English level
凹ginner
$\square$ ntermediate
Advanced

\begin{tabular}{|c|c|c|c|c|c|}
\hline \multirow{4}{*}{ 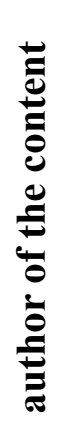 } & Criteria & 1 & 2 & 3 & 4 \\
\hline & 1- Users can link to information about the sponsor and author & & & & \\
\hline & $\begin{array}{l}\text { 2- The author is an expert or is qualified to deliver reputable } \\
\text { resources }\end{array}$ & & & & \\
\hline & 3- Users can contact authors for clarification & & & & \\
\hline 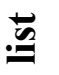 & 4- The listening comprehension takes place in authentic & & & & \\
\hline
\end{tabular}

$(1=$ I strongly care, $2=$ I partly care, $3=\mathrm{I}$ do not care, $4=\mathrm{I}$ do not care at all $)$ 


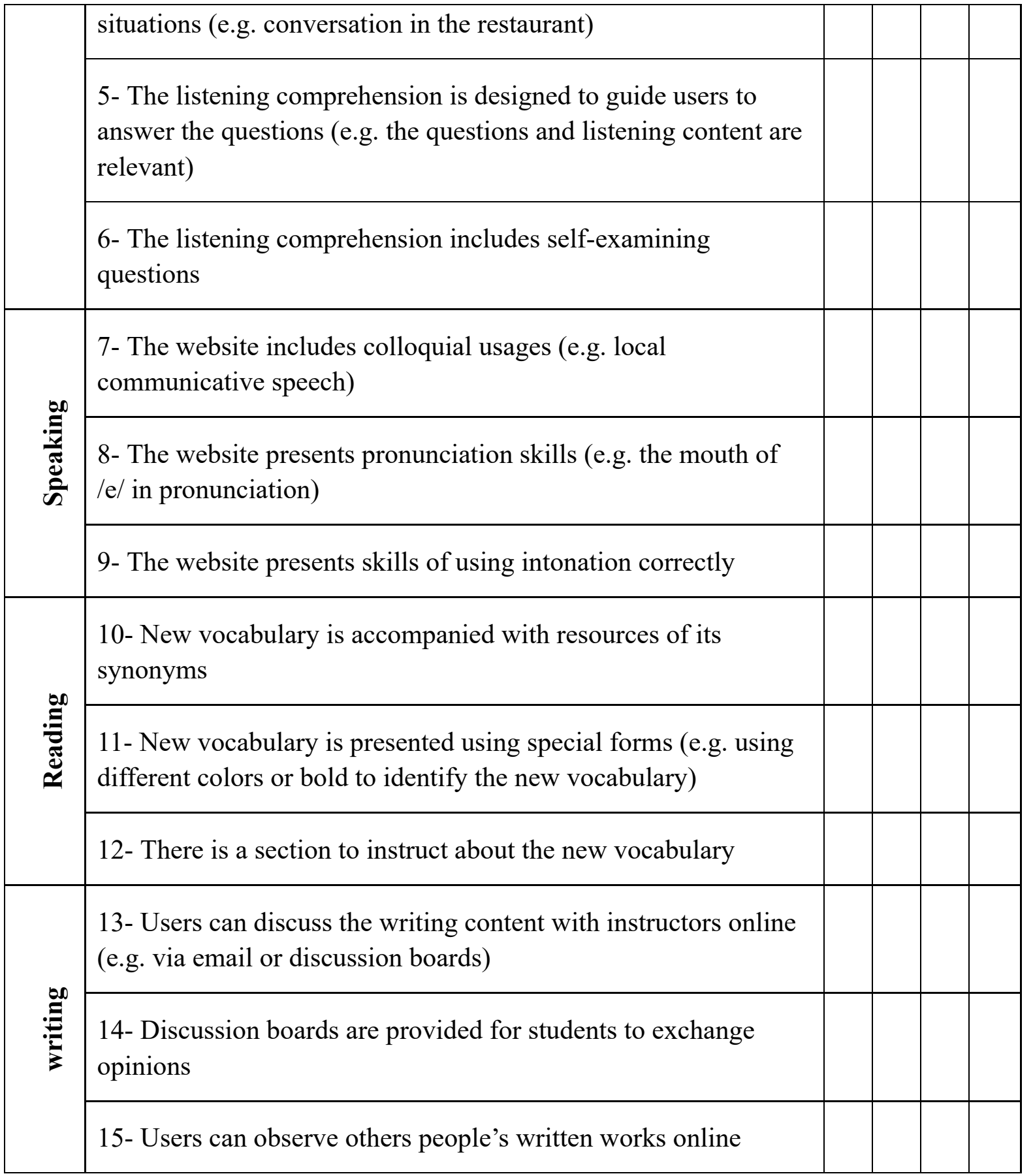

Note: the items of this questionnaire are adapted from: Yang and Chan (2008)

\section{Copyright Disclaimer}

Copyright reserved by the author(s).

This article is an open-access article distributed under the terms and conditions of the Creative Commons Attribution license (http://creativecommons.org/licenses/by/4.0/). 